\title{
TOLONG-MENOLONG DALAM PENYELENGARAAN PESTA PERNIKAHAN PADA MASYARAKAT BUGIS DI DESA MADELLO KABUPATEN BARRU SULAWESI SELATAN
}

\author{
Oleh: Dr. Mahmud Tang, M.A.' ")
}

\begin{abstract}
In this article I try to describe the activitity of helping each other in the celebration of wedding party at Buginese society in Madello village Barru regency South Sulawesi. The principal of helping each other which I observed was in the form of giving service, goods, and money to the parents of bridegroom and bride. These activities of helping each other are based on the principle of reciprocity from customary law and religious law. It seems that the moslem were earlier practiced these principle tfian the publish of Malinowski's finding in Trobriand Island (1926). In my assumption, the activity of helping each other at the Buginese wedding will exist in the future as long as they obey to their customary law and religious law.
\end{abstract}

Key words: Helping each other, celebration of wedding party, and the principle of reciprocity.

\section{PENDAHULUAN}

$\mathrm{P}$ enyelenggaraan pernikahan merupakan suatu institusi sosial yang amat penting, dalam ajaran Islam maupun dalam adat istiadat Bugis.

Dalam ajaran Islam diperintahkan kepada para wali untuk mengawinkan orang yang masih sendirian, sebagaimana firman Allah.SWT surah an-Nur, ay at 32:

"Dan kawinkanlah orang-orang yang sendirian di antara karnu, dan orang-orang yang layak dari hamba sahaya kamu yang laki-laki dan hamba sahaya kamu yang perempuan. Jika mereka miskin Allah akan memampukan mereka dengan karunianya, dan Allah maha luas (pemberian-Nya) lagi maha mengetahui."

〈إ Penulis adalah Dosen Program Studi Antropologi FISIPOL UNHAS Makassar. 


\section{Mahmud Tang}

Menurut M.Quraish Shihab bahwa ayat di atas menyatakan : Hai para wali, para penanggung jawab bahkan seluruh kaum muslimin : perhatikanlah siapa yang berada di sekeliling kamu dan kawinkanlah yakni bantulah agar dapat kawin orang-orang yang sendirian di antara kamu, agar mereka dapat hidup tenang dan terhindar dari perbuatan zina dan yang haram lainnya, dan seterusnya. ${ }^{2}$ Selanjutnya, dalam tradisi Islam melangsungkan perkawinan yang diketahui secara umum dianggap sebagai sunnah.

Ajaran Islam seperti diuraikan di atas, bagi orang Bugis tidak bisa ditawartawar atau harus dipatuhi. Bagi orang Bugis hubungan intim antara laki-laki dan perempuan tanpa didahului oleh penyelenggaraan pesta pernikahan adalah merupakan perbuatan yang sangat memalukan (mappakasiri'). Perbuatan memalukan dalam konteks ini bagi orang Bugis bukan hanya dirasakan sebagai beban moral keluarga inti yang bersangkutan, tetapi juga merupakan aib (sin") yang ditanggung oleh seluruh anggota kerabat dekat yang termasuk dalam kelompok siassirikeng siapppessei (satu kelompok harga diri dan solidaritas bersama). ${ }^{4}$ Penjelasan yang mendalam tentang prosedur pernikahan masyarakat ada Bugis dan Makassar daapat dilihat dari tulisan S.B. Miller. ${ }^{5}$

Proses penyelenggaraan pesta pernikahan pada masyarakat Bugis sangat dipengaruhi oleh aturan adat sehingga pihak yang menyelenggarakannya memerlukan banyak bantuan dalam rangka mematuhi aturan-aturan adatnya. Karena itu mulai dari awal pelaksanaanya (peminangan) sampai akhir acara bermalam tiga malam (mabbbenni tellummpenni) kaum kerabat, tetangga, sekampung, dan sahabat-sahabat memberikan bantuan atau pertolongan baik berupa tenaga, bahan makanan, dan uang.

Dalam kebudayaan Bugis, tolong menolong dalam rangka penyelenggaraan perkawinan dianggap sebagai kewajiban sosial yang dilandasi oleh hukum adatnya. Kemudian dengan masuknya agama Islam, maka hal itu sekaligus menjadi kewajiban agama. Dalam surah Al-Maidah ayat 2 Allah.SWT berfirman: "Dan tolong-menolonglah kamu dalam kebajikan dan ketakwaan, dan janganlah tolong-menolong dalam dosa dan pelanggaran." Menurut Quraish Shihab bahwa ayat ini merupakan perinsip dasar dalam menjalin kerjasama dengan siapa pun, selama tujuannya adalah kebajikan dan ketakwaan. ${ }^{6}$

Artikel ini berupaya untuk mendeskripsikan kegiatan tolong-menolong dalam penyelenggaraan pesta pernikahan orang Bugis di Desa Madello Kabupaten 
Barru. Sebagai satu pendekatan antropologi hukum, maka saya akan mengungkapkan hukum-hukum atau prinsip-prinsip yang mendasari kegiatan tolong-menolong tersebut, baik itu bersumber dari adat, ataupun agama. Karena dalam masyarakat Bugis memang terdapat keanekaragaman (pluralisme) hukum yang bersumber dari adat, agama, dan negara.

Data yang dipakai dalam artikel ini adalah hasil penelitian kami yang disponsori oleh Bureau Indonesische Studien pada tahun 1990 dan penelitian yang disponsori oleh BAPPENNAS RI pada tahun 2002 di Desa Madello Kabupaten Barru. Kunjungan selanjutnya ke desa itu kami selalu lakukan dalam rangka menghadiri pesta pernikahan (terakhir awal tahun 2009 yang lalu).

Desa Madello terletak di pesisir pantai yang mayoritas penduduknya adalah petani kecil dan sebagian lagi adalah nelayan kecil. Mereka hidup dalam kelompok-kelompok kerabat, ponggawa-sawi yang masih kuat sikap tolongmenolongnya dalam proses produksi pertanian dan perikanan, serta dalam penyelenggaraan pesta atau upacara lingkaran hidup terutama pernikahan.

\section{TEMUAN DAN PEMBAHASAN}

\section{Tolong-Menolong dalam Proses Penyelenggaraan Pesta Pernikahan}

\section{Peminangan}

Sesudah pihak keluarga laki-laki menjatuhkan pilihannya pada seorang gadis, sebelum meminang atau melamar secara resmi, orangtua calon mempelai lakilaki lebih dahulu mengutus salah seorang diantara anggota keluarganya untuk menyelidiki apakah gadis yang diingini itu belum atau sudah ada yang mengikatnya. Kalau utusan itu telah mendapat jawaban pasti bahwa belum ada yang mengikatnya, maka selanjutnya ia berusaha untuk mengetahui apa dapat diterima apabila ia melamar gadis itu. Urusan ini harus dilakukan secara hati-hati dan secara rahasia sebab kalau tidak berhasil dan diketahui oleh orang lain maka pihak keluarganya akan merasa malu (masiri'). Seperti diungkapkan pula oleh Errington bahwa urusan perkawinan erat hubungannya dengan masalah siri', karena dalam proses pelaksanaannya gampang sekali terjadi kesalahpahaman yang menimbulkan konteks siri'. ${ }^{8}$ Menurut Matthes bahwa orang Belanda pada masa yang lalu juga merasa sangat terhina apabila lamarannya ditolak.' Karena itu, untuk melakukan urusan ini diperlukan bantuan dari anggota keluarga yang dianggap berpengalaman. Kalau hasil penyelidikan itu positif semuanya maka langkah selanjutnya dilakukan lamaran secara resmi (madduta). 


\section{Mahmud Tang}

Untuk melamar secara resmi diperlukan bantuan dua orang atau lebih (laki- • laki dan perempuan), di mana orangtua laki-laki sendiri tidak ikut serta. Salah seorang di antaranya bertindak sebagai juru bicara. Untuk tugas ini pihak keluarga laki-laki memilih anggota keluarganya atau orang yang dianggap sebagai Tomatua (orang yang dituakan dalam masyarakat, pemimpin informal) yang berpengalaman dalam urusan ini. Sebaik-baiknya apabila dilakukan oleh seorang Tomatua yang berpengaruh kepada kedua belah pihak. Hal ini pernah dilakukan oleh H. SH untuk mengawinkan LC (pengikutnya) dengan anak gadis dari pengikutnya yang lain. Urusan seperti itu seringkali dilakukan oleh seorang Tomatua untuk mengawinkan kemanakan atau pengikutnya dengan anak pengikutnya yang lain (kasus perkawinan BR dengan anak penggarap sawah pamannya). Menurut Ibu ST bahwa sewaktu Daeng Patobo (Tomatua di Kampung La Pao) masih hidup tidak ada orang yang berani menolak apabila ia menyampaikan lamaran seseorang kepada orangtua gadis.

Apabila lamaran itu telah diterima oleh pihak keluarga gadis, untuk suatu proses peminangan bagi orang kebanyakan, maka pada kesempatan itu juga kedua belah pihak membicarakan jumlah mas kawin (sompa) dan uang belanja ( $d m$ balanca) yang merupakan kewajiban pihak keluarga laki-laki untuk biaya pelaksanaan upacara/pesta pernikahan itu. Meskipun pemberian "hadiah sebagai tanda pengikat" (passio) dan barang-barang lainnya (Use' sompara') telah diatur oleh adat, namun adakalanya masih diingatkan lagi oleh pihak keluarga perempuan agar tidak diabaikan. Selain itu, ditentukan pula waktu untuk pertemuan berikutnya dalam rangka mempertunangkan kedua calon pengantin dan sekaligus mengantar sebagian ataupun seluruh uang belanja (mappenre' balanca).

Akhirnya, suatu peminangan dilanjutkan dengan suatu acara yang disebut "membuat kesepakatan" (mappasiarekeng). Acara ini dihadiri oleh beberapa orang dari kedua belah pihak. Jumlah mereka puluhan bahkan mencapai ratusan orang apabila mereka bermaksud untuk meramaikannya. Pak Amrullah masih mengingat ketika Pak Sa'ad dinikahkan acara mappasiarekeng dihadiri oleh sekitar 50 orang. Pada saat anak gadis DB akan dikawinakan, pihak keluarga laki-laki ada lebih sepuluh orang yang datang mappasiarekeng, begitu pula anggota keluarga DB ada sekitar dua puluh orang yang hadir dalam acara itu. Dalam kesempatan seperti itu kedua belah pihak menampilkan anggota kerabatnya yang dianggap terhormat, seperti yang sudah haji, pegawai, pemuka masyarakat, terutama yang ditampilkan sebagai juru bicara. Mereka yang ditampilkan dalam pertemuan itu masing-masing berpakaian adat Bugis atau 
sebagiannya berpakaian biasa tapi rapi. Dalam kedatangannya itu, pihak lakilaki mengantarkan barang-barang yang bersifat simbolis. Sebaliknya, pihak keluarga perempuan menyambut mereka dengan persiapan makanan yang terdiri atas kue-kue berbagai macam yang dihidangkan. Materi pembicaraan mereka antara lain penentuan hari dan tanggal upacara pernikahan, pakaian yang akan dipakai oleh pengantin dan siapa yang akan menanggung sewanya, jumlah pengantar pengantin laki-laki (pappenre' hotting), dan seterusnya.

\section{Persiapan Pesta Pernikahan}

Sebelum orangtua pengantin memulai kegiatannya dalam rangka persiapan dan pelaksanaan upacara/pesta perkawinan anaknya, terlebih dahulu berkonsultasi dengan orang yang dianggapnya sebagai Tomatua. Di lain pihak, seorang yang merasa diri diperlakukan sebagai Tomatua dan diberi wewenang untuk memberikan pengarahan untuk kelancaran jalannya upacara/pesta itu merasa turut bertanggung jawab dalam pelaksanaan upacara/pesta perkawinan itu. Ketika ND akan menikahkan anak gadisnya ia datang menyampaikan dan memohon bantuan PJ untuk berperan sebagai Tomatua dalam pesta itu. Setelah ia kembali ke rumahnya, PJ mengatakan pada saya, "Kalau orang menyerahkan urusannya secara penuh kepada kami, maka kami pun membantunya secara penuh pula". Dalam kasus ND tersebut dia bukannya tidak beralasan untuk mengharap bantuan dan kesediaan PJ. Dia seperti yakin bahwa PJ pasti akan membantunya sebab antara dia dan isteri PJ sama-sama berasal dari Tanete di mana status orangtua ND sebagai pengikut (klien) dari isteri PJ.

Untuk melakukan persiapan bagi suatu upacara dan pesta pernikahan tuan rumah memerlukan banyak bantuan terutama bantuan tenaga untuk melakukan berbagai kegiatan praktis, tetapi juga berbagai hal yang memerlukan tenaga ahli. Karena itu, untuk melakukan kegiatan secara terorganisasi, maka orang Madello terlebih dahulu membentuk suatu panitia persiapan dan pelaksanaan upacara/pesta pernikahan. Panitia itu mengadakan rapat untuk melakukan pembagian tugas. Pada pernikahan anak ND tersebut di atas, PJ (sebagai Tomatua) yang memimpin rapat panitia. Dalam susunan panitia itu PJ berperan sebagai penasehat bersama dengan Imam Dusun Madello dan Kepala Dusun Madello. Selanjutnya, penasehat menunjuk ketua, sekertaris dan bendahara, berikut pembagian seksi: seksi peralatan dan bangunan; seksi undangan; seksi konsumsi; seksi dekorasi; seksi hiburan; seksi kesehatan; seksi keamanan; seksi protokol; seksi segi empat (domino); seksi penjemputan; seksi penerangan dan seksi kendaraan. 


\section{Mahmud Tang}

Sesudah penasehat membentuk seksi-seksi tersebut. dan menunjuk orangorang yang bertugas di setiap seksi, lalu sekretaris diminta oleh penasehat untuk membacakan kembali susunan panitia. Selanjutnya, penasehat mempersilakan kepada hadirin untuk memberikan tanggapan kalau ada yang perlu ditambahkan ataupun dikurangi. Temyata tidak ada yang memberikan komentar, dus semuanya seolah-olah langsung saja menyetujui tugas-tugas yang dipercayakan kepada mereka. Hal itu tidak mengherankan sebab penasehat itu mengetahui benar kemampuan atau keahlian masing-masing orang yang diharapkan bantuannya. Selanjutnya penasehat menanyai masing-masing seksi bahwa kapan mereka akan memulai kegiatannya. Pada saat penasehat sampai pada urusan lampu pada PLN, bukannya dia menanyakan bagaimana seksi penerangan/lampu menghubungi PLN, tetapi menanyakan siapa di antara yang hadir itu yang sanggup melakukan tugas itu. Ternyata salah seorang dari seksi keamanan (seorang polisi) yang bersedia menghubungi PLN. Dus, meskipun pembagian tugas sudah ditentukan namun dalam urusan-urusan tertentu seseorang dapat membantu pelaksanaan tugas seksi lainnya. Di samping itu, orang yang tidak tercatat sebagai anggota panitia, misalnya staf desa meskipun tanpa diminta bantuannya secara langsung, namun mereka manawarkan bantuannya untuk membantu seksi undangan dalam hal pengetikan undangan.

Setelah penasehat mengecek kesanggupan dan rencana kerja masingmasing seksi, ia kembali mengingatkan beberapa hal yang dianggap penting sehubungan dengan aturan adat yang harus diperhatikan terutama bagi seksi undangan yang akan berhubungan dengan banyak orang pada saat mengantarkan undangan. Pengetikan nama orang yang akan diberikan kartu undangan harus diketik secara benar. Selanjutnya semua anggota rombongan pembawa undangan harus masuk ke dalam rumah orang secara kekeluargaan dan tidak boleh sebagian tinggal di motor dan sebagian lainnya masuk rumah. Begitu pula orang yang 'turut mengundang' (namanya ikut tercantum sebagai pengundang) diperingatkan supaya hadir untuk menjemput kedatangan orang yang diundangnya.

Setelah selesai rapat panitia, maka setiap seksi mulai menyusun rencana kerja. Seksi yang mendesak tugasnya segera memulai bekerja. Apabila sisa waktu persiapan kurang dari dua minggu lagi, terutama seksi undangan harus segera mengetik nama dan alamat orang yang akan diundang dan selanjutnya mengantarkannya satu per satu. Untuk tugas seksi undangan diperlukan beberapa orang. Rombongan yang bertugas untuk mengantarkan undangan bagi lapisan orang kebanyakan diperlukan dua sampai empat orang: 2 pemuda dan 2 yang 
biasanya berboncengan dengan menggunakan sepeda motor, yaitu pria membonceng wanita yang memegang undangan. Rombongan lainnya, yang bertugas untuk mengantarkan undangan bagi orang-orang terhormat (lapisan bangsawan dan pejabat), terdiri atas 8-10 orang dewasa dan tua-tua yang biasanya menggunakan mobil untuk jarakjauh. Apabila pelaksanaan upacara/ pesta itu diadakan secara sederhana saja biasanya orang dalam kampung diundang secara selektif saja yaitu terbatas pada keluarga dekat, tetangga dan sahabat saja.

Pada masa persiapan itu di antara anggota keluarga dekat, orang yang dianggap atau disamakan dengan keluarga (sinyawa-nyawa), sahabat-sahabat (appada buraneng), patron atau pun klien berusaha untuk memberikan sumbangan tidak hanya sekedar sumbangan tenaga, tetapi adajuga yang berupa bahan makanan dan uang. Mereka yang berkebun atau berladang di dataran tinggi mengantarkan sumbangan berupa sayur-sayuran, kelapa, pisang, gula merah, daun pisang untuk membungkus kue-kue tradisional, dan lain-lain. Sedangkan mereka yang tinggal di pulau-pulau kecil atau menggarap empang di pinggir pantai mengantarkan ikan, yang pada gilirannya akan diantarkan beras oleh keluarganya yang bertani. Menurut keterangan dari Petta Museng (tokoh masyarakat) bahwa sebelum tahun 1960-an keluarga dekat pada menyumbang padi kepada anggota keluarganya yang mau mengawinkan anaknya. Mereka yang tidak mampu menyumbangkan bahan makanan akan berusaha untuk menghadiri undangan keluarganya dengan menyumbangkan sekurang-kurangnya tenaga. Keluarga dekat yang dari luar kampung datang menginap dua atau tiga malam dengan maksud untuk dapat menyumbangkan tenaga semaksimal mungkin. Bahkan kalau mereka tidak mampu menyumbangkan apa-apa pun tetap datang untuk menampakkan dirinya (mappitangngi alena).

Sumbangan bahan makanan tersebut diperlukan untuk dikonsumsi sejak pada malam rapat panitia, pada hari-hari selanjutnya sampai pada puncak upacara. Keluarga dekat, tetangga dan sahabat mulai beramai-ramai datang membantu melakukan pekerjaan-pekerjaan praktis kira-kira seminggu atau selambat-lambatnya tiga hari sebelum puncak acara. Tenaga laki-laki terutama dibutuhkan pada saat membangun tambahan ruangan atau 'sambungan rumah' (sumpung bola) atau mendirikan tenda (mappatettong tenda) yang biasanya dilakukan selambat-lambatnya dua hari sebelum puncak acara. Pekerjaan ini merupakan tugas utama seksi peralatan dan bangunan, tetapi dalam kenyataannya pekerjaan itu diselesaikan secara gotong-royong oleh anggota masyarakat yang beramai-ramai datang. Pada saat ini, banyak orang yang lebih 
suka menyewa dan memasang tenda saja di halaman rumahnya dan tidak perlu lagi membangun sambungan rumah seperti tempo dulu. Tetapi meskipun pemasangan tenda hanya memerlukan 5-10 tenaga laki-laki, namun kalau tuan rumah "suka turun" (panno) maka akan datang sekitar 50 orang, sehingga kadang-kadang banyak tenaga yang tidak terpakai secara efisien. Bersamaan dengan pemasangan tenda atau penyambungan rumah, seksi peralatan dari kaum wanita juga melakukan tugasnya meminjam peralatan dapur dari tetangga, seperti piling, gelas, cangkir, mangkuk, dan sebagainya. karena barang-barang tsb. sudah diperlukan juga pada hari itu. Selain itu, seksi konsumsi yang diketuai oleh seorang yang sehubungan dengan tugasnya itu disebut Paddawa-dawa yang memimpin wanita lainnya bekerja di dapur untuk mempersiapkan makanan. Kalau lakilaki mendirikan tenda di pagi hari, maka wanita mempersiapkan makan siang untuk mereka yaitu nasi dan lauk-pauknya, sedangkan kalau dilakukan di sore hari maka makanan disiapkan dalam bentuk kue-kue.

Setelah tenda atau sambungan rumah siap, seksi peralatan melanjutkan tugasnya dengan mengisi ruangan itu dengan kursi. Seksi penerangan mengatur peyambungan aliran listerik, seksi dekorasi menghiasi ruangan itu, berikut seksi keamanan menjaga jangan sampai peralatan yang sudah dipersiapkan itu ada yang disalahgunakan sampai rusak. Setelah tambahan ruangan itu siap, pada malam harinya seksi domino boleh memanfaatkannya dengan mengadakan pertandingan domino. Pertandingan itu bukan sekedar untuk mengejar hadiah bagi pemenang sebab hadiahnya tidak besar, bukan pula sekedar sebagai penyaluran hobbi, tetapi lebih daripada itu adalah sekaligus berjaga-jaga semalam suntuk agar peralatan dan persiapan lainnya tidak kecurian. Selain itu, anakanak muda yang hanya sebagai penonton saja sewaktu-waktu dapat diminta bantuan tenaganya oleh ibu-ibu yang memerlukan bantuan tenaga laki-laki untuk mengangkat barang yang berat-berat. Dalam prakteknya, sejak terpasangnya tenda atau sambungan rumah, terus-menerus keluarga dekat dan tetangga ramairamai datang untuk bersiap-siap kalau-kalau tenaganya diperlukan atau sekedar datang meramaikan suasana dengan beramah-tamah. Di lain pihak, kaum wanita perlu mengimbangi jumlah laki-laki yang datang agar pelayanan makanan dapat berjalan lancar. Setiap orang yang datang disuguhi makanan sesuai dengan waktu makan, karena itu tidak henti-hentinya juga ibu-ibu mempersiapkan makanan di dapur.

Sejak masa persiapan itu tuan rumah kadang-kadang mulai mencemaskan kemungkinan terjadinya hal-hal yang tidak diinginkan, seperti pecahnya peralatan yang dipinjam, kalau-kalau bahan makanan cepat habis secara boros. Untuk 
mengatasi kemungkinan-kemungkinan negatif itu, maka tuan rumah memerlukan bantuan dari orang yang mempunyai ilmu khusus di bidang itu, tetapi ia tidak pernah tercatat dalam daftar seksi-seksi yang telah dibentuk. Ia seolah-olah berperan di balik layar.

\section{Tudampenni/Mappacci}

Acara Tudampenni yaitu berkumpul bersama keluarga dan tetangga pada malam menjelang hari pernikahan akan dilangsungkan pada keesokan harinya yang diisi berbagai kegiatan antara lain pembacaan do'a selamat (mabbaca doang salama'), adakalanya juga orang baru sempat mengadakan upacara penamatan Al qur'an (mappanre temme') bagi calon mempelai atau keluarga dekat lainnya, pembacaan barasanji, dan suatu upacara khusus yang menurut adat harus dilakukan malam itu yaitu Mappacci sehingga di samping sebutan Tudampenni orang juga menyebutnya Mappacci. Mappacci dari kata pacci yang dihubungkan dengan kata paccing artinya bersih. Jadi malam mappacci diartikan malam mensucikan diri. Untuk pelaksanaan upacara agama (Islam) dan adat tersebut, sebagai satu rangkaian kegiatan dalam rangka pelaksanaan upacara pernikahan, diperlukan bantuan orang-orang tertentu untuk memimpin dan ikut berperan aktif dalam upacara tsb. Upacara pembacaan do'a selamat untuk leluhur tuan rumah dan juga untuk Nabi (Petta Nabie, maksudnya nabi Muhammad), serta penamatan Al qur'an dipimpin oleh imam dusun.

Pembacaan barasanji pada malam itu menurut orang Bugis Madello seolaholah telah menjadi kewajiban sosial, sehingga tidak ada acara Tudampenni atau Mappacci tanpa diisi dengan pembacaan barasanji. Dalam acara pembacaan barasanji itu diperlukan sekitar tujuh orang untuk berperan secara aktif dan hadirin lainnya ikut meramaikannya. Pada saat pembacaan barasanji sampai pada "Asrakal badrun alaaina, dan seterusnya." maka upacara mappacci langsung dimulai sementara pembacaan barasanji tetap diteruskan. Karena upacara itu adalah upacara adat, maka nampaknya tidak harus dimulai oleh Puak Imang. Pada upacara mappacci anak perempuan Petta Mamu dimulai oleh Pak Desa dan dilanjutkan berturut-turut oleh Imam Desa, Imam Dusun, Kepala Dusun, tokoh-tokoh masyarakat lainnya dan haji-haji yang termasuk keluarga dekat dari calon pengantin itu.

Menurut Sapada bahwa jumlah orang yang meletakkan daun pacci di tangan calon mempelai disesuaikan dengan stratifikasi sosial calon mempelai yang bersangkutan, dimana untuk golongan bangsawan tertinggi $2 \times 9$ orang (duakkasera). Golongan bangsawan menengah $2 \times 7$ (duakkapetu), sedangkan 
untuk golongan di bawahnya $1 \times 9$ atau $1 \times 7$ orang. Tetapi pada waktu sekarang ini pelapisan sosial tidak lagi mempengaruhi jumlah itu. ${ }^{10}$ Pada akhir-akhir ini di Madello jumlah itu juga tidak bergantung lagi pada pelapisan sosial calon mempelai, tetapi seberapa orang yang hadir di dalam acara itu yang memenuhi permintaan keluarga yang bersangkutan. Pada upacara mappacci anak PM ada 11 orang yang dipilih untuk meletakkan daun pacci di tangannya. Dus, jumlah itu tidak pas dengan salah satu dari jumlah yang berdasarkan atas aturan adat tersebut di atas.

Pada prinsipnya bahwa orang yang diharapkan kerelaannya dalam pelaksanaan upacara ini ialah mereka yang tergolong kedudukan sosialekonominya tinggi atau yang keadaan rumahtangganya nampak bahagia. Sehingga diharapkan bahwa rumahtangga baru yang akan dibentuk itu kelak mendapatkan keberuntungan sebagaimana halnya orang-orang yang meletakkan daun pacci di tangan calon pengantin itu. Setiap orang yang selesai meletakkan daun pacci di tangan calon pengantin disuguhi rokok sebagai pengganti daun sirih. Indo' hotting atau salah seorang keluarga dekat, biasanya dipilih yang sudah haji, yang mendampingi calon pengantin dalam upacara itu sesekali menaburkan kembang beras ke atas kepala calon pengantin.

Setelah selesai upacara mappacci dihidangkan makanan untuk semua orang yang hadir dalam acara itu. Anggota keluarga dekat, tetangga dan sahabatsahabat tuan rumah yang menghadiri acara Tudampenni atau Mappacci ratarata sekitar 50-an laki-laki dan wanita yang memasak di dapur lebih banyak dari jumlah laki-laki sebab tenaga wanita lebih banyak dibutuhkan. Tenaga wanita di rumah calon mempelai laki-laki selain yang sibuk mempersiapkan masakan, sebagian lainnya mempersiapkan kue-kue dan jenis masakan lainnya serta hadiahhadiah (kokkong-kokkong) yang akan diantar ke rumah celon mempelai wanita. Pada saat ID menikah, isteri PJ (Tomatua) mempersiapkan semua kue-kue adat yang akan diantar ke rumah pengantin perempuan. Menurut isteri PJ bahwa ID adalah pemuda yang rajin membantu kalau ada keperluan tenaga; lagi pula orangtuanya banyak jasa-jasanya di masa lalu. Sampai kini, acara Tudampenni masih tetap dilakukan sebagai satu rangkaian acara dalam pesta perkawinan secara adat.

\section{Menre Rawing}

Menreq kawing yaitu pengantin laki-laki diantar ke rumah pengantin wanita untuk dinikahkan oleh penghulu. Acara ini merupakan salah satu inti dari seluruh rangkaian upacara pernikahan. Keberangkatan pengantin laki-laki ke rumah 
pengantin wanita diantar oleh keluarga dekat, tetangga dan sahabat-sahabatnya. Di antara pengantar itu terdapat orang-orang terhormat dari keluarga dekat, orang-orang yang dianggap sebagai Tomatua antara lain kepala desa dan pemuka masyarakat yang lainnya, berikut pemuda-pemuda yang diharapkan membantu mengangkat kue-kue adat yang ditempatkan di dalam bosara' dan buah-buahan yang ditempatkan di dalam wolasuji, dan dara-dara muda yang akan membantu mengangkat bingkisan hadiah-hadiah yang berupa seperangkat pakaian dan perhiasan untuk pengatin wanita. Selain itu, dibutuhkan juga bantuan tenaga dari seorang laki-laki untuk membawa 'mas kawin' (sompa) yang dibungkus dengan kain putih bersama dengan benda-benda simbolis lainnya dan seorang laki-laki tua (pappakkarawa) yang akan mengantar pengantin laki-laki untuk memegang (makkarawa) isterinya untuk pertama kalinya sesudah dinikahkan. Keseluruhan orang yang mengantar pengantin laki-laki disebut Pattiwi Botting atau Pappenre' Botting.

Dari pagi sebelum pengantar pengantin laki-laki datang, seksi konsumsi dan seluruh perempuan yang bekerja di dapur nampak sibuk mempersiapkan makanan yang akan dihidangkan kepada pengatar pengatin laki-laki. Begitu pula Indo' Botting yang bertugas untuk merias pengatin melaksanakan tugasnya mengenakan pakaian yang akan dipakai oleh pengatin laki-laki yang disesuaikan dengan pakaian pengatin wanita. Kalau Indo' Botting tidak sempat datang sendiri ke rumah pengantin laki-laki karena ia sedang sibuk di rumah pengantin wanita, maka ia hanya mengirimkan pakaian itu dan pengantin laki-laki dibimbing oleh salah seorang yang dianggap lebih tahu. Kalau pengatin menggunakan pendamping (ball botting) yang biasanya adik kandung atau adik sepupu dari pengantin laki-laki itu, maka ia juga mengenakan pakaian yang sama dengan pakaian pengantin laki-laki.

Sesudah pengantin lengkap dengan pakaiannya, pengantar juga sudah pada datang dan sudah disuguhi makanan, kendaraan sudah menunggu, maka diperhitungkanlah waktu untuk perjalanan supaya tidak terlambat tiba di rumah pengantin wanita. Sebelum ID berangkat ke rumah calon isterinya, PJ terlebih dahulu memeriksa daftar nama-nama mereka yang sudah bertandatangan untuk mengantar dan menanyakan apakah mereka sudah datang semua. Demikian pula pada saat bahan makanan (Use bosara') dan buah-buahan akan diangkat ke mobil tenaga dikerahkan oleh PJ (Tomatua) sebab tidak sembarang orang yang mau mengangkat barang-barang antaran itu berdasarkan atas kedudukan mereka dalam pelapisan sosial dan hubungan kekerabatannya dengan pengantin laki-laki itu. 
Jumlah pengantar kadang-kadang dibatasi sesuai dengan perjanjian antara ke dua belah pihak, apabila ruangan yang disediakan atau kemampuan pihak pengantin wanita agak terbatas. Sebab kalau tidak dibatasi ada kalanyajumlah pengantar terlalu banyak sehingga pihak pengantin wanita tidak mampu melayaninya semua dan dalam keadaan seperti itu bukan hanya keluarga wanita yang malu (masirV) tetapi juga keluarga pengantin laki-laki.

Pada hari pernikahan, yaitu hari kedatangan pengantin laki-laki ke rumah pengatin wanita, merupakan puncak kesibukan di rumah pengantin wanita yang dimulai dari pagi-pagi untuk mempersiapkan segala sesuatunya dalam rangka penyelenggaraan puncak upacara pernikahan hari itu. Dus, seksi konsumsi masih saja terus melanjutkan pekerjaannya mempersiapkan bahan makanan. Pagi itu yang pertama diberi makan adalah semua orang yang hadir di dalam rumah itu yang dari pagi membantu dalam berbagai kegiatan. Berikut persiapan makanan untuk pengantar pengatin laki-laki dan tamu-tamu yang telah diundang. Bersamaan dengan itu, seksi dekorasi kembali melengkapi perhiasan yang belum selesai.

Pagi itu juga Indo' Botting merias pengantin wanita dan pendampingnya (balinna bottinnge). Pendamping bagi pengantin wanita tersebut biasanya adik kandung atau sepupu dari pengantin itu sendiri atau anggota keluarga dekat lainnya yang sama status sosialnya dengan pengantin itu.

Menjelang kedatangan pengantin laki-laki para penjemput yang terdiri atas keluarga dekat dari pengantin wanita telah bersiap-siap pula. Keluarga yang dianggap berstatus tinggi, antara lain para haji dan orang-orang yang dianggap sebagai Tomatua atau terkemuka dalam masyarakat sangat diharapkan berperan aktif dalam penjemputan rombongan pengatin pria dan tamu-tamu yang telah diundang. Di antara penjemput itu terdapat pembagian tugas yang memerlukan beberapa tenaga, antara lain seorang wanita tua dari keluarga dekat pengantin yang bertugas menyambut pengantin laki-laki dengan menaburkan bertih ke kepalanya sebagai ucapan selamat datang, seorang atau dua orang (biasanya saudara laki-laki dari pengantin perempuan) yang menjemput pengantin lakilaki (padduppa botting) dari kendaraannya dan mengantarnya naik ke rumah. Beberapa orang di antaranya lagi ditugaskan untuk menjemput dan mengantar orang-orang tertentu yang dianggap sebagai tamu terhormat ke tempat duduk yang sesuai dengan kedudukan sosial mereka. Sebagian besar penjemput lainnya berdiri berbaris mengapit jalanan yang akan dilalui oleh rombongan pengantin laki-laki. Apabila tuan rumah menyewa band atau orkes maka pemain-pemainnya 
pun sibuk mempersiapkan dan selanjutnya memainkan peralatannya. Pada tahun 1990 yang lalu, apabila orangtua pengatin wanita menerima uang belanja satu juta atau lebih maka dianggap sebaiknya menyewa band.

Pada waktu makan siang sekitar jam 11.00 semua orang yang telah bekerja dari pagi dan juga yang baru datang untuk menjemput pengantin laki-laki semuanya diberi makan. Apabila persediaan daging agak terbatas maka pada kesempatan makan ini penyajian daging masih dikontrol ketat olehpaddawa-dawa, sehingga lauk-pauk lebih banyak berupa ikan dan sayur-sayuran. Sesudah mereka makan semua, barulah persediaan daging dikeluarkan sebanyak mungkin untuk disajikan kepada rombongan pengantin laki-laki. Biasanya segala sesuatunya telah siap sebelum rombongan pengantin laki-laki datang.

Pada saat pengantin laki-laki tiba di depan rumah pengantin wanita, ia dijemput dan diantar naik ke rumah oleh saudara atau keluarga terdekat dari pengantin wanita dan pada saat sampai di tangga ia ditaburi bertih oleh seorang wanita sebagai ucapan selamat datang. Seorang laki-laki (pappakkarawa) yang akan mengantar pengantin pria untuk pertama kalinya "memegang isterinya" (makkarawa) berjalan beriringan dengan pengantin pria. Di antara anggota rombongan pengantar itu, anggota rombongan yang membawa kuekue adat yang diletakkan dalam bosara' menyerahkan kue-kue itu kepada pihak pengantin wanita lalu mencari tempat duduk sendiri, sedangkan dara-dara muda yang membawa 'hadiah yang berupa seperangkat pakaian dan perhiasan wanita' (kokkong-kokkong) langsung naik ke rumah dan menempati tempat duduk yang disediakan bagi mereka.

Sebelum pengantin laki-laki dinikahkan terlebih dahulu pembawa mas kawin (sompa) dan uang belanja (did balanca atau did menre') menyerahkan uang itu kepada pihak keluarga pengantin perempuan lalu dihitung oleh imam atau yang dianggap sebagai Tomatua dan disaksikan oleh hadirin lainnya. Pada perkawinan anak perempuan LS, uang belanja dihitung oleh Imam dan selanjutnya dihitung kembali oleh kakak ipar pengantin. Sedangkan pada perkawinan anak perempuan DB, uang belanja dihitung oleh PJ dengan disaksikan oleh anggota anggota kerabat dekat DB. Pada tahun 1990 yang lalu uang belanja yang umum di Madello sebesar satu juta rupiah, di samping itu ada kekhususan-kekhsusan bagi mereka yang berhak menerima paling rendah yaitu lima ratus ribu rupiah (kasus anak LS, golongan ekonomi lemah) dan yang paling tinggi ketika itu dua setengah juta rupiah (kasus anak HS, orang kaya). Ada pun maskawin (sompa) yang jumlahnya sesuai dengan pelapisan sosial pengantin 


\section{Mahmud Tang}

perempuan yang bersangkutan tidak pernah berubah sejak dahulu dan disebutkan dalam mata uang Arab (rial). Selanjutnya pengantin laki-laki dinikahkan oleh imam dengan disaksikan oleh dua orang saksi yang bekerjasama dengan imam. Sesudah dinikahkan, pengantin laki-laki diantar oleh pappasikarawa ke kamar di mana pengantin perempuan sedang duduk didampingi oleh Indo' Botting dan keluarga dekat lainnya.

Biasanya Indo' Botting tidak langsung membuka pintu kamar pengatin sehingga terjadi percakapan singkat antara pappasikarawa dengan Indo' Botting. Setelah pappasikarawa menyelipkan uang kertas masuk ke dalam kamar itu sebagai uang pembuka pintu barulah Indo' Botting membuka pintu. Selanjutnya pengantin laki-laki dibimbing oleh pappasikarawa untuk memegang atau menyentuh isterinya sambil Indo 'Botting melindungi pengantin perempuan jangan sampai kepalanya yang dipegang. Terdapat anggapan bahwa kalau pengantin laki-laki memegang kepala isterinya itu berarti bahwa ia mengharapkan isterinya lebih dahulu meninggal. Sesudah itu ke dua mempelai itu duduk sejenak dalam kamar itu, lalu bersama-sama ke luar menuju pelaminan untuk duduk bersanding dengan disaksikan oleh pengantar pengantin laki-laki, keluarga besar pengantin perempuan dan tamu-tamu (undangan).

Setelah ke dua mempelai duduk bersanding beberapa saat, lalu mereka pergi "memohon maaf (mellau addampeng) dan do'a restu dari ke dua orangtua pengantin perempuan. Setelah itu mereka kembali duduk bersanding, untuk penyelenggaraan upacara perkawinan yang agak resmi, diadakan sambutan dari pihak keluarga pengantin wanita untuk menyatakan terima kasih kepada semua pihak yang telah memberikan sumbangan baik berupa materil atau pun moril dan permohonan maaf apabila terdapat kekurangan atau pun kekeliruan dalam pelayanan mereka. Sambutan itu disusul dengan nasehat perkawinan yang dibawakan oleh salah seorang pemuka agama Islam. Ke dua acara tersebut biasanya diawali dengan pembacaan Al-qur'an oleh salah seorang pembaca yang terlatih. Pada kesempatan itu tamu-tamu yang telah diundang pada datang. Mereka langsung berjabatan tangan dengan ke dua mempelai sambil mengucapkan selamat berbahagia dan menaruh envelop yang telah diisi dengan uang sumbangan (passolo) atau hadiah (pabbere) berupa barang pada tempat yang telah disediakan, lalu mencari tempat duduk yang kosong atau ditunjukkan tempat duduk oleh salah seorang dari keluarga pengantin perempuan. Orang-orang terhormat dari lapisan bangsawan dan pemuka masyarakat diantar ke tempat duduk yang dianggap pantas baginya. Semua pengantar pengantin laki-laki dijamu dengan nasi, daging dan sayur-sayuran. Demikian pula tamu- 
tamu atau undangan lainnya yang datang kemudian. Setelah mereka selesai makan, sekali lagi menyalami ke dua mempelai dan meninggalkan rumah pengantin perempuan.

\section{Marola}

Untuk lengkapnya pelaksanaan tata cara perkawinan yang dilakukan berdasarkan atas adat Bugis, maka dilakukan acara Marola (letterlijk: mengikut) yaitu kunjungan pengantin perempuan ke rumah pengantin laki-laki) sesudah pelaksanaan upacara petnikahan di rumah pengantin perempuan. Menurut Sapada bahwa dulu acara marola di kalangan bangsawan dilakukan tiga kali." Pada masa kini, untuk menghemat tenaga dan biaya orang orang melakukannya satu kali saja.

Pada acara marola keluarga dekat dari pengatin perempuan, terutama anggota keluarga yang mempunyai status sosial tinggi diharapkan bersedia mengantar pengantin perempuan (lao mapparola) ke rumah pengantin laki-laki. Di pihak lain, anggota keluarga dari pengantin laki-laki (diutamakan yang berstatus tinggi) diharapkan kedatangannya untuk menjemput rombongan pengantin perempuan. Dalam kunjungan itu pihak keluarga pengantin perempuan membawa kue-kue sebagai balasan dari kue-kue (Use bosara) yang telah diterima dari pihak keluarga pengantin laki-laki. Pada saat pengantin perempuan tiba ia dijemput oleh salah seorang dari keluarga dekat pengantin laki-laki. Setelah sampai di depan tangga untuk naik ke rumah salah seorang perempuan tua menaburi pengantin perempuan itu dengan bertih sebagai tanda ucapan selamat datang (pappakuru' sumange'). Begitu pula pengantarnya dijemput dan ditunjuki tempat duduk sebagaimana halnya perlakuan pihak pengantin perempuan. Salah satu rangkaian dari acara marola itu ialah penyerahan hadiah balasan kepada orangtua pengantin laki-laki yang berupa sarung sutera dalam suatu acara khusus yang disebut "mappammatua" (terjemahan bebas: persembahan kepada mertua). Penyerahan hadiah itu diserahkan oleh pengantin perempuan itu sendiri dengan ditemani oleh Indo 'Botting atau diwakili oleh salah seorang bibinya atau keluarga dekatnya. Sebagai reaksi positif dari orangtua pengantin laki-laki bahwa setelah pemberian itu diterima diserahkan kembali kepada pengatin perempuan, bahkan ditambah lagi dengan berbagai hadiah-hadiah (pabbere) untuk menutupi sebagian dari kebutuhan pokok rumahtangga baru itu sesuai dengan kemampuan orangtua pengantin laki-laki. Tempo dulu, menurut Matthes bahwa pada kunjungan pengantin perempuan ke rumah pengatin laki-laki ia diberi hadiah berupa tanah atau sawah-ladang. Pada saat ini, umumnya pengantin pria dan wanita kembali ke rumah pengantin wanita pada hari itu juga (marola siesso). 


\section{Mahmud Tang}

\section{Mabbenni Tellumpenni dan Massita Baiseng}

Setelah ke dua pengantin baru itu menginap di rumah pengantin perempuan, pada keesokan harinya pihak keluarga pengantin laki-laki apakah secara langsung dilakukan oleh orangtua pengantin laki-laki itu atau diwakili oleh keluarga dekatnya "mengunjungi besannya" (massita baiseng) sambil menjemput menantunya untuk "bermalam tiga malam" (mabbenni tellumpenni) di rumah orangtua pengantin laki-laki. Menurut keterangan dari orang-orang tua bahwa tempo dulu acara mabbenni tellumpenni betul-betul dilakukan dengan bermalam selama tiga malam. Pada saat ini acara ini dilakukan hanya semalam saja dan keesokan harinya ke dua pasangan baru itu kembali ke rumah orangtua pengantin perempuan. Dalam kunjungan itu pengantin perempuan masih mendapat berbagai macam pemberian dari pihak keluarga suaminya.

Setelah selesainya orangtua pengantin laki-laki massita baiseng dan juga pengantin perempuan telah mabbenni tellumpenni di rumah mertuanya, maka prosedur perkawinan menurut tatacara adat telah selesai. Akan tetapi upacara dan pesta pernikahan yang dilakukan secara resmi yang dimulai dengan "pembentukan panitia", maka biasanya diadakan pula acara pembubaran panitia yang dilakukan bersamaan atau pun setelah selesainya ke dua acara tersebut. Biasanya acara pembubaran panitia diawali dengan acara barasanji dan doa' selamat sebagai tanda syukur atas telah terselenggaranya upacara dan pesta perkawinan itu. Bersamaan dengan acara pembubaran panitia diadakan pula acara pembukaan amplop. Amplop dibuka satu pesatu sambil disebutkan berapa isinya dan salah seorang menulis nama dan berapa isi amplopnya. Isi amplop berkisar antara Rp. 3.000- Rp. 5.000. Beberapa orang menyumbang kurang dari Rp. 3.000 juga ada yang lebih dari Rp. 5.000.- (data tahun1990).

Pada ke esokan harinya sebagian dari peralatan rumahtangga yang dipinjam dari tetangga dikembalikan kepada pemiliknya. Bersamaan dengan pengembalian barang-barang tersebut kue-kue dan bahan makanan lainnya yang tersisa dibagibagikan yang sebagiannya diantarkan ke pada orang-orang yang dikembalikan barang-barangnya sebagai tanda terima kasih dan balasan atas bantuannya. Begitu pula kepada orang-orang yang telah berjasa menyumbangkan tenaganya, terutama bagi 'mereka yang tinggal menginap dan mencurahkan tenaganya untuk pekerjaan berat seperti mengambil air, memasak, dan mencuci piring (tau monro maddusung) dan juga mereka yang membantu menghidangkan makanan (sebagai pelayan) diberikan balas-jasa berupa hadiah-hadiah yang diambilkan dari kado-kado. Beberapa informan menyebutkan bahwa anggota keluarga yang 
miskin dan tinggal bekerja selama berlangsungnya upacara perkawinan itu selain diberikan imbalan berupa hadiah-hadiah, juga diberikan kembali uang sumbangannya (passolona).

\section{KESIMPULAN}

Deskripsi tentang penyelenggaraan pesta pernikahan di atas, telah diketahui bagaimana orang Bugis di Desa Madello tolong-menolong dalam bentuk pemberian bantuan berupa tenaga, bahan makanan, dan uang. Bantuan tersebut bersumber dari anggota kerabat, baik yang ada di dalam kampung maupun yang tinggal di daerah lain. Begitu pula bantuan diperoleh dari tetangga, sekampung terutama bantuan tenaga untuk pekerjaan praktis seperti mengambil air bersih, kayu bakar, memasak, dan sebagainya. Dari mereka juga diperoleh bantuan bahan makanan, dan yang sangat pen ting artinya adalah bantuan berupa uang yang diberikan di dalam amplop.

Hukum-hukum dan prinsip-prinsip yang mendasari tolong-menolong tersebut dapat dirujuk ke hukum adat atau norma-norma sosial yang mengharuskan orang tolong-menolong (sitidung-tulung), saling membantu (sibantu-bantu), saling mendatangi kalau diundang (siturungi) dalam suka dan duka, terutama mereka yang mempunyai hubungan kekerabatan (asseajingeng), pertetanggaan (abbalibolangeng) dan persekampungan (assikampongeng). Sumbangan yang diberikan dalam bentuk uang (passolo), disamping ada orang yang memberikannya dengan tanpa pamrih (ikhlas), umumnya orang menganggapnya sebagai investasi social (parutang) yang oleh pihak penerima dicatat baik-baik dan akan dibalas pada masa yang akan datang.

Tindakan tolong-menolong tersebut di atas dapat juga dirujuk ke hukum Islam, yaitu perintah Allah untuk-"tolong-menolong dalam kebaikan" dan perintah Allah untuk "membantu orang yang menikah atau menikahkan orang yang dalam tanggung jawabnya". Selain itu, tolong-menolong dapat juga dirujuk kepada anjuran Rasulullah Muhammad saw untuk memenuhi hakhak tetangga dan seтиa orang yang mengundang dalam rangka pesta pernikahan. Tolong-menolong dalam hal ini dapat juga dikaitkan dengan sunnah Rasulullah untuk tukar-menukar hadiah antar individu untuk mempererat hubungan. Dalam prakteknya, sumbangan yang diterima dalam pesta pernikahan tidak langsung dibalas pada waktu yang sama tetapi dicatat baikbaik oleh pihak penerima untuk dibalas pada saat pemberi bantuan melakukan acara yang sama atau serupa di masa yang akan datang. 
Mahmud Tang

Jadi, orang Islam telah mengamalkan prinsip resiprositas (principle ofreciprocity) jauh sebelum B. Malinowski mengumumkan temuannya tentang prinsip resiprositas yang berlaku sebagai hukum di kepulauan Trobriand. Bedanya, di dalam Islam ditegaskan bahwa diharamkan pemberian bantuan atau hadiah dengan maksud-maksud tertentu seperti yang disebut oleh Malinowski sebagai pengaruh motif-motif personal, social dan psikologi yaitu ingin dipuji (vanity), perasaan bangga atas pemberian yang dilakukan (pride), dan ingin dianggap hebat (desire of self enhancement by display), tetapi Islam menganjurkan apa yang disebut Malinowski sebagai pemberian yang didorong oleh perasaan kasih sayang (attachment), persahabatan (friendship), ketaatan dan kesetiaan pada hukum (devotion of loyalty to the law) $\}^{2}$

Tidak semua bantuan yang diterima dibalas secara sempurna (perfect balance.) Kita lihat misalnya jasa yang diberikan oleh kepala desa pada saat memimpin rapat panitia yang akan bertugas dalam penyelenggaraan suatu pernikahan, begitu pula pada saat memulai suatu acara mappacci, yang disusul oleh imam desa, imam dusun, kepala dusun, dan tokoh masyarakat lainnya. Begitu pula pelaksanaan acara pembacaan barasanji yang dipimpin oleh imam desa beserta imam dusun yang diikuti oleh kepala desa, kepala dusun, dan pemuka masyarakat lainnya. Kesemuanya itu tidak perlu diberi balasan yang seimbang oleh pihak yang menerima bantuan. Bantuan seperti itu dalam pandangan antropolog M. Sahlins disebut generalized resiprocity (pemberian bantuan secara ikhlas atau tanpa pamrih). ${ }^{13}[*]$.

\section{CatatanAkhir:}

Penulis adalah Dosen Program Studi Antropologi FISIPOL UNHAS.

M. Quraisy Shihab. 2005. Tafsir Al-Misbah, vol.3. Jakarta: Lentera Hati., h. 334.

Ibrahim Al-Kaisy, M. 2002. Yang Pantas dan Patut bagi Seorang Muslim. Moral and Manner. Jakarta: Srigunting.. h. 157.

“Lihat Selly Erington. 1977. "Siri', Darah dan Kekuasaan Politik di dalam Kerajaan Luwu Dulu", dalam Bingkisan Budaya Sulawesi Selatan. . Usamah Akademis.

${ }^{5}$ S.B. Miller. 1983. Bugis Society: Given by the Wedding Guest. Cornell University.

${ }^{6}$ M. Quraish Shihab. op.cit., h. 14 
'Mahmud Tang> 1996. Aneka Ragam Pengaturan Sekuritas Sosial di Bekas Kerajaan Berru Sulawesi Selalan, Indonesia. Wageningen-Nederland: Grafisch Service Centrum Van Gils BV. Penjelasan yang mendalam tentang konsep prulisme hukumbaca J. Griffith. 1986. "What is Legal Pluralism?", in Journal of Legal Pluralism 24: 1-50.

${ }^{8}$ Lihat Errington. op.cit., h. 57-59

' B.F. Mathes. 1875. Bijdragen rot de Ethnologie van ZuidCelebes's. Gravenhage., h. 13.

${ }^{10}$ A.N. Sapada. t.t. Tata Rias Pengantin dan Tata Cara Perkawinan Bugis-Makassar. Ujung Pandang: Agung Lestari., h. 27.

"Ibid.

${ }^{12}$ Lihat Malinowski.1926. Crime and Custom in Savage Society. London: Kegan Paul., h.58. Bandingkan pula dengan Mahmud Tang dkk. 2002. Perlindungan Sosial di Wilayah Perkotaan dan Pedesaan Sulawesi Selatan. Kerjasama jurusan Antropologi FISIP UNHASBAPPENNAS RI.

${ }^{13}$ M. Sahlin. 1974. Stone Age Economics. London: Routledge. 


\section{Daftar Pustaka}

Errington, S. 1977. "Siri', Darah dan Kekuasaan Politik di dalam Kerajaan Luwu Dulu", dalam Bingkisan Budaya Sulawesi Selatan. Usamah Akademis.

Griffiths, J. 1986. "What is Legal Pluralism?", in Journal of Legal Pluralism 24: $1-50$.

Ibrahim Al-Kaisy, M. 2002. Yang Pantas dan Patut bagi Seorang Muslim. Moral and Manner. Jakarta: Srigunting

Malinowski, B. 1926. Crime and Custom in Savage Society. London: Kegan Paul.

Matthes, B.F. 1875. Bijdragen tot de Ethnologie van Zuid Celebes, 's Gravenhage: Gebroeders

Millar, S. B. 1983. Bugis Society: Given by the Wedding Guest. Cornell University.

Quraish Shihab, M. 2005. Tafsir Al-Misbah, vol.3. Jakarta: Lentera Hati.

Sahlins, M. 1974. Stone Age Economics. London: Rouledge.

Sapada, A. N. t.t. Tata Rias Pengantin dan Tata Cara Perkawinan BugisMakassar. Ujung Pandang: Agung Lestari.

Tang, M. 1996. Aneka Ragam Pengaturan Sekuritas Sosial di Bekas Kerajaan Berru Sulawesi Selatan, Indonesia. Wageningen-Nederland: Grafisch Service Centrum Van Gils BV.

Tang, M. dkk. 2002. Perlindungan Sosial di Wilayah Perkotaan dan Pedesaan Sulawesi Selatan. Kerjasama jurusan Antropologi FISIP UNHAS-BAPPENNAS RI. 